\title{
Educative Function of Law in the Fragmented International Legal Order Case of Right to Water v. Investment Protection
}

\section{Educative Function of Law}

The very fundamental function of law is to direct human behavior: to maintain and preserve social peace and order. When legal regulations are coherent with other types of social norms, they provide individual and collective stabilization, as they are secured by the state's coercion.

Law may also promote social, cultural and economic change. Depending on predefined political paradigms, law has a capacity to direct transformations. ${ }^{1}$ Especially in the area of human rights, which are strongly correlated with other types of norms and out-of-law values, law may promote evolutions which are in a line or in opposition to social preferences.

By incorporating values to legal norms, a lawmaker affirms and promotes them as socially relevant and worth to be protected by the state's coercion. Legislator's affirmation also plays an educative function. Particularly, acts of general nature like constitutions or certain international conventions play the "educative" role and may shape society's axiology. In this context, not only substance but also form and construction of legal acts are of particular importance. The order of legal norms in a particular act may indicate the hierarchy of incorporated institutions or values. ${ }^{2}$

1 See: T. Chauvin, T. Stawecki, P. Winczorek, Wstẹp do prawoznawstwa, Warszawa 2011, p. 168; J. Jabłońska-Bonca, Wprowadzenie do prawa. Introduction to Law, Warszawa 2008, p. 22; L. Morawski, Wstęp do prawoznawstwa, Toruń 2006, pp. 28-30; A. Ko r yb ski, L. Leszczyński, A. Pien iążek, Wstẹp do prawoznawstwa, Lublin 2007, pp. 47-48.

${ }^{2}$ E.g. Interpretation of the Constitution of the United States where Presidential Veto Clause was placed in art. I describing the powers of the Congress serves as an evidence of legislative nature of this power; separate art. I, II and III related distinctively to legislative, executive and judicial branches proof the principle of the separation of powers; A.R. A m ar, 'Intratextualism', Harvard Law Review, Vol. 112, No. 4 (1999), p. 747, http://dx.doi.org/10.2307/1342297; 
Legal norms on human rights are usually located in constitutions and international conventions. As a consequence of legal hierarchy, they have a capacity to influence whole legal systems. ${ }^{3}$ The general nature of human rights regulations even strengthens this effect.

In particular cases, the broad character of human rights norms requires concretization by judicial branch. Jurisprudence, even if in theory serving as a subsidiary source of law, ${ }^{4}$ becomes a fundamental indicator in resolving particular conflicts of values. The decisions of courts related to human rights may also play a significant role in legal education of a society. As they relate to fundamental aspects of social standards which are very often of moral and ethical nature, they have a capacity to attract a particular attention of public opinion. The role of courts is of primordial character in case of conflicts with values stemming from other subsystems of fragmented international law.

\section{Specificity of International Law: Fragmentation}

Since at least a decade, the fragmentation of international law has been a phenomenon which attracts attention of not only international lawyers but also of legal philosophers, political scientists and other experts. ${ }^{5}$ It constitutes the very specificity of international law. Most of legal branches are distinguished on the criterion of object, i.e. a matter which they regulate: e.g. family law, labor law, commercial law, penal law etc. The international law is distinguished on the ground of method of regulation and its subjects. Its primary subjects are the states which mostly rely on methods of international treaties and custom. International law may relate to any object and becomes "international" when it is regulated by states on supranational level. The multitude of objects within legal system provokes its fragmentation.

similarly art. 26 of the Polish Penal Code (published in Dziennik Ustaw, 1997, Vol. 78 Item 483) which regulates the state of necessity, requires that "the interest sacrificed has a lower value than that of the interest rescued" - a systematic and contextual interpretation of the Act, based on the order of protected values in the Code provides and answer in comparison of "interests".

${ }^{3}$ According to art. 27 of the Vienna Convention on the Law of Treaties, United Nations Treaty Series, Vol. 1155, p. 679, internal law may not be invoked as justification for a failure to perform a treaty, therefore international treaties are usually placed over domestic acts in legal hierarchy, see e.g.: Art. 91 para. 2 of the Constitution of the Republic of Poland, Dziennik Ustaw, 1997, Vol. 78 Item 483; art. 25 of the Basic Law for the Federal Republic of Germany (Grundgesetz), Federal Law Gazette, 23 May 1949.

${ }^{4}$ See: Art. 38 para. 1(d) of the Statue of the International Court of Justice, 26 June 1945, United Nations Treaty Series, Vol. 33, p. 993.

s See: 'Conclusions of the work of the Study Group on the Fragmentation of International Law. Difficulties arising from the Diversification and Expansion of International Law', Yearbook of the International Law Commission, Vol. 2 (2006), Part Two, at <http://untreaty.un.org/ilc/ texts/instruments/english/draft\%20articles/1_9_2006.pdf>, 23 December 2012. 
Moreover, as a system it is developed by a plurality of lawmakers, works of which are often uncoordinated. Moreover, due to globalization, the amount of legal norms produced on supranational level has been constantly growing - the rising amount of issues are regulated or co-regulated by instruments of supranational nature. International regulations devoted to specific issues are enacted by specialized organs and bodies, which cannot always preview all possible conflicts with other norms of international law stemming from its other subsystems. This problem of multipolar lawmaking and a lack of a single body of constitutional rules provides that international legal order is at least potentially less coherent than domestic systems. Therefore, international courts and tribunals play a crucial role in resolving conflicts stemming from different norms of fragmented subsystems.

\section{Investment v. Human Rights Protection}

The split between human rights and investment protection is based on a paradox. Human rights and investment proceedings are based on a similar scheme: an individual's or an investor's claim against a violation of international law by public authorities. The very fundamental goals of investment treaties are to provide protection against expropriation and discrimination of economic operators and to assure a right to a fair and impartial trial. Right to property, protection against non-discrimination and a right to due process are at the same time one of the fundamental human rights. ${ }^{6}$ Therefore, it is not surprising that several disputes led to parallel claims on human rights and investment grounds. ${ }^{7}$ Moreover, international investment disputes arbitrators relied on human rights decisions in their reasoning. For example, in Roland S. Lauder v. Czech Republic case, the court evoked the distinction between "formal" and "de facto expropriation" which appeared in Mellacher v. Austria case before European Court of Human Rights (hereinafter ECHR). ${ }^{8}$ Similar situation took place in Técnicas Medioambientales S.A. v. Mexico where reference was made to the report of Inter-American Court of Human Rights in Ivcher Bronstein v. Peru decision ${ }^{9}$ and Matos e Silva v. Portugal which was used

6 E.g. Art. 6, 14 of the Convention for the Protection of Human Rights and Fundamental Freedoms; Art. 1 of the Protocol 1 to that Convention, United Nations Treaty Series, Vol. 213, p. 262.

7 See: U. Kriebaum, 'Is the European Court of Human Rights an Alternative to InvestorState Arbitration?' in P.-M. Dupuy, E.-U. Petersman n, F. Francioni (eds.), Human Rights in International Investment Law and Arbitration, Oxford 2009, pp. 219-245.

* Ronald S. Lauder v. Czech Republic, 2001 WL 34786000, UNCITRAL Final Award, 3 September 2001, para 200, at <http://italaw.com/sites/default/files/case-documents/ita0451 . pdf>, 4 December 2012; quoting Mellacher v. Austria, Eur. Ct. H.R., Vol. 169, (ser. A) (1989).

9 Técnicas Medioambientales S.A. v. United Mexican States, ICSID Case No. ARB(AF)/00/2, 29 May 2003, para 119, at <https://icsid.worldbank.org/ICSID/FrontServlet? request Type=Cas esRH\&actionVal=showDoc\&docId=DC602_En\&caseId=C186>, 4 December 2012; quoting 
to explain the principle of proportionality. ${ }^{10}$ Therefore, the legal reasoning in two branches of international law may be mutually inspiring. The dichotomy between investment law and human rights is of economic background. Where human rights law is rather perceived to protect the weak, investment protection may appear as legal tool of rich multinational companies which often seek compensation against developing states.

\section{Water Shortages and International Law}

The recognition of human right to water as a distinct human right is rather recent. Several universal conventions have mentioned it. The 1979 Convention on the Elimination of Discrimination against Women obliged the state-parties to liquidate discrimination and assure the right of women to enjoy adequate water supply. ${ }^{.1}$ Similarly, the 1989 Convention on the rights of the child recognizes the states shall combat disease and malnutrition through the provision of adequate foods and clean drinking-water. ${ }^{12}$ However, the recognition of the right to water as a universal and separate human right was done in General Comment No. 15 $(2002)^{13}$ of Articles 11 (right to adequate housing and adequate food) and 12 (right to the highest attainable standard of health) of International Covenant on Economic, Social and Cultural Rights. ${ }^{14}$ On 28 July 2010, through Resolution 64/292, ${ }^{15}$ the United Nations General Assembly explicitly recognized the human right to water and sanitation and acknowledged that clean drinking water and sanitation were essential to the realization of all human rights. ${ }^{16}$

The recognition of a freestanding human right to water is a result of growing water shortages in different areas. Due to different phenomena like urbanization, population growth and rising industrial production, the demand for water has been

Inter-American Court of Human Rights case Baruch Ivcher Bronstein v. Peru, 6 February 2001, paras 120-124, at <http://corteidh.or.cr/docs/casos/articulos/seriec_74_ing.pdf>, 4 December 2012.

1" European Court of Human Rights, In the case of Matos e Silva, Lda., and Others v. Portugal, judgment of 16 September 1996, para 85, at <http://hudoc.echr.coe.int>, 4 December 2012.

1 Art. 14(2)(h) of the Convention on the Elimination of Discrimination against Women, New York, 18 December 1979, United Nations Treaty Series, Vol. 1249, p. 13.

12 Art. 24(1)(c) of the Convention on the Rights of the Child, done at New York, 20 November 1989, United Nations Treaty Series, Vol. 1577, p. 3.

13 Committee on Economic, Social and Cultural Rights, Geneva, 11-29 November 2002, General Comment No. 15 (2002), E/C.12/2002/11, 20 January 2003.

is United Nations Treaty Series, Vol. 993, p. 3.

is Resolution adopted by the General Assembly 64/292. The human right to water and sanitation, A/RES/64/292, 3 August 2010.

16 See: <http://www.un.org/waterforlifedecade/human_right_to_water.shtml>, 10 December 2012 . 
growing. The "blue gold" becomes a scarce good. Nevertheless, water deficits are mostly of relative character: there is a lack of water in a given time and given place. International community tries to face this phenomenon. The recognition of human right to water gives it a "human right perspective" when water governance invokes legal regulations stemming from different subsystems of international law. Water management invokes also regulations of international environmental law and international economic law. The expressed recognition gives it an additional dimension. The international economic law provides a double track answer to the growing water demand. The first alternative is the international water trade. Technology progress makes water transport more affordable and requiring less infrastructural costs. ${ }^{17}$ However, water deficits are due not only to water availability, but also to the lack of infrastructure. Water supply and sanitation by a system of pipelines is relatively expensive and not every state may afford it. Therefore, their construction requires investments which are not always affordable for public funding. In consequence, many states were forced to demand for foreign funding and the international investment law became relevant in assuring the human right to water. The recognition of human right to water is also a result of collision of this still emerging right with different internationally protected values, like investment protection.

\section{International Investments in Water Projects}

International investment often takes place when states are unable to fund themselves costly infrastructural projects. Privatization of services, which traditionally remained in public sphere, was due to at least two reasons. First, the definitive fall of the communism as an economic system seemed to indicate that only capitalism and privatization may serve as efficient tools of management. Secondly, the global tendency of trade liberalization was followed by dynamism of capital flows and investment. This would not be possible without the growing network of bilateral investment treaties which fostered foreign direct investment. They guaranteed protection to investors against expropriation, non-discrimination and a right to international arbitration proceedings. The privatization strategy was also promoted and required as a condition of the World Bank's co-financing of the project. $^{18}$

Privatization often did not bring the expected results. In Bolivian city of Cochabamba the public opinion criticized the lack of transparency in awarding

17 For example with the use of flexible barge (waterbags), see more details on <http://www. waterbag.com>, 4 December 2012.

14 Suez, Sociedad General de Aguas de Barcelona S.A., and InterAgua Servicios Integrales del Agua S.A. and The Argentine Republic, Decision on Liability, 10 July 2010, ICSID Case No. ARB/03/17, para 33; Biwater Gauff (Tanzania) Ltd. v. United Republic of Tanzania, 24 July 2008, ICSID Case No. ARB/05/22, para 3. 
the concession and was afraid of the future water rates. ${ }^{19}$ In other Argentinean provinces, like Tucumán, some political options expressed "most solid opposition to transferring the patrimonies of the Province" when an investor doubled the water prices to the contractual maximum stipulated in the concession. ${ }^{20}$ In the province of Buenos Aires, the investor faced considerable difficulties in collecting its rates what provoked discontinuation in its previously agreed expansion program. ${ }^{21}$ Similar situation took place in Dar-es-Salaam. ${ }^{22}$ In Argentinean Santa Fe, the state's financial crisis and depreciation of currency put the investor into an economically critical situation which, however, was not followed by the authorities' consent for raising the rates. ${ }^{23}$ The refusal was linked with a "repeated calls of the Provincial governor and the other officials for non-payment of the bills by customers". ${ }^{24}$

The changing economic situation often pushed investors or states to renegotiate the contract of lease, which was unsuccessful. ${ }^{25}$ Companies experiencing difficulties tried to exercise pressure on non-paying consumers by interrupting water services. However, in case of Impregilo v. Argentine this right was suspended. ${ }^{26}$ Such failure led to unilaterally announced termination of contract which amounted to expropriation..$^{27} \mathrm{~A}$ similar scenario took place in Vivendi case. ${ }^{28}$ In Cochabamba, the developments were more dramatic. The raise of water prices from 25 to 200 percent in a short period after the privatization agreement resulted in rebellion. ${ }^{29}$ The civil unrest provoked in imposition of martial law and re-nationalization of water savings company. ${ }^{30}$

The deprivation or termination of concession formed an alleged expropriation. States used different arguments to justify their decisions. The right to water in context $\mathrm{o}$ international investment law appeared in different contexts.

${ }^{19}$ Aguas del Tunari, S.A. v. Republic of Bolivia, Decision on Respondent's Objections to Jurisdiction, ICSID Case No. ARB/02/3, 21 October 2005, paras 63-66.

20 Compañía de Aguas del Aconquija S.A. and Vivendi Universal S.A. v. Argentine Republic, 20 August 2007, Case No. ARB/97/3, para 4.8.2, 4.9.1.

21 Impregilo S.p.A. v. Argentine Republic, 21 June 2011, ICSID Case No. ARB/07/17, para 21.

22 Biwater..., para 163.

${ }^{23}$ Suez, Sociedad General de Aguas de Barcelona S.A., and InterAguas Servicios Integrales del Agua S.A. v. the Argentine Republic, Decision on Jurisdiction, 16 May 2006, ICSID Case No. ARB/03/17, para 24.

24 Ibid., para 376.

25 Biwater..., para 200; Suez..., Decision on Jurisdiction, paras 24-25.

26 Impregilo..., paras 19, 39.

27 Biwater..., para 519.

28 Vivendi..., paras 4.18.1-4.18.6.

${ }^{24}$ W. Schreiber, 'Realizing the Right to Water n International Investment Law. An Interdisciplinary Approach to BIT Obligations', Natural Resources Journal, Vol. 438, p. 435.

3) Ibid., p. 436. 


\subsection{State of Necessity}

In Suez v. Argentine, the respondent-state was seeking defense of its actions by invoking the state of necessity. ${ }^{31}$ Argentine argued that it

adopted measures in order to safeguard the human right to water of the inhabitants of the country. Because of importance to the life and health of the population, Argentina states that water cannot be treated as an ordinary commodity. Because of the fundamental role of water in sustaining life and health and the consequent human right to water, it maintains that in judging the conformity of governmental actions with treaty obligations this Tribunal must grant Argentina a broader margin of discretion in the present case than in cases involving other commodities and services. ${ }^{32}$

The parties to the dispute agreed, that the customary international law regulating the necessity is reflected in Article 25 of the International Law Commission's (ILC) Articles on the Responsibility of States for Internationally Wrongful Acts (2001). ${ }^{33}$ Its invocability is conditioned by several premises. One of them assumes that the measures taken constitute the only way to safeguard an essential interest. ${ }^{34}$ In a given case, despite the severe character of the crisis acknowledged by the arbitrators, the Tribunal was not convinced that the only way that Argentina and the Province could satisfy that essential interest was by adopting measures that would subsequently violate the treaty rights of the Claimants. ${ }^{35}$

The Province could have attempted to apply more flexible means to assure the continuation of the water and sewage services to the people of Santa Fe and at the same time respected its obligations of fair and equitable treatment. The two were by no means mutually exclusive. ${ }^{36}$

Another condition which the arbitrators assessed as unfulfilled was the "noncontribution of the situation of necessity". ${ }^{37}$ In their opinion the term "to contribute" should be distinguished from expressions like "to cause" or "to create". ${ }^{38}$ Thus, the fact that other actors, besides the State in question, may have contributed to that State's situation of necessity does not automatically mean that such State has

${ }^{31}$ Suez v. Argentine..., Decision on Liability, paras 229 and subsequent.

32 Ibid., para 232.

33 Ibid., para 229; International Law Commission (ILC), Draft Articles on Responsibility of States for Internationally Wrongful Acts with commentaries, November 2001, Supplement No. 10 (A/56/10), at <http://untreaty.un.org/ilc/texts/instruments/english/commentaries/9_6_2001.pdf>, 13 December 2012.

3 See: ILC, Draft..., art. 25(1)(a).

35 Suez v. Argentine..., Decision on Liability, paras 235-238.

36 Ibid., para 238.

37 See: ILC, Draft..., art. 25(2)(b).

34 Suez v. Argentine..., Decision on Liability, para 241. 
not contributed to it. ${ }^{39}$ The Tribunal found that a combination of endogenous and exogenous factors contributed to the Argentine crisis and such contribution was sufficiently substantial "and while exogenous factors did fuel additional difficulties they do not exempt the Respondent from its responsibility in the matter". ${ }^{40}$

In sum, the Tribunal assessed the lack of fulfillment of the "necessity test". Despite of that, its analysis serves the educational goal of law. First, it admits the possible interactions between international investment and human rights regulations. Secondly, it does not exclude the possibility of taking advantage of human rights based arguments in shaping the scope of investment protection. Third, it seems that if the crisis was provoked by purely external factors and the state, due to its situation would lack an alternative method of providing water to its inhabitants, the tribunal's conclusion could be different. Obviously, the two factors are of gradual nature. Nevertheless, the reasoning provided in the decision leaves space for potential limits of investment protection based on human rights premises.

\subsection{Amicus Curiae Participation}

The right to water was an issue raised by several non-governmental organizations which are active in the area of human rights and showed interest in participating in the investment procedures. The Tribunal in Biwater v. Tanzania ${ }^{41}$ accepted the petitioners as third parties to the dispute. It did so, despite the opposition of the claimants, and argued it by a need of "information and submissions on the issues in dispute from all relevant standpoints" which are "of concern to the wider community in Tanzania". 42 As in the case of Methanex v. USA, the involvement of amicus curiae was justified by "public interest [...] which arises from its subject matter. [...] There is also a broader argument, [...] the [...] arbitral process could benefit from being perceived as more open or transparent".43 Therefore, opening the process to amicus curiae submissions would contribute to another principle and human right: the one of due, transparent, public and impartial process.

By admitting the amicus submissions, the arbitrators stated that "petitioners would address broad policy issues concerning sustainable development, environment, human rights and governmental policy".44 Those fields were indicated as being within the ambit of Rule 37(2)(a) of the ICSID Arbitration Rules which require

\footnotetext{
3y Ibid.

11) Ibid.

41 Biwater..., para 356 and sequent.

12 Ibid., para 358.
}

43 Methanex v. United States of America, Decision on Petitions from Third Persons to Intervene as Amici Curiae, 15 January 2001, para 49, at <http://www.state.gov/documents/organization/6039.pdf>, 2 August 2013.

44 Biwater..., para 366. 
them to be "a factual or legal issue related to the proceeding". 45 In consequence the tribunal admitted the domain of human rights as issue related to the proceedings. The amici's observations were estimated as useful and relevant to which the tribunal declared to return in particular context. ${ }^{46}$

In Biwater v. Tanzania the amici stated that "investor responsibility [...] must be assessed in the context of sustainable development and human rights" which condition the nature of investor's responsibilities. ${ }^{47}$ They related to numerous declarations according to which "water is a key to sustainable development". Access to clean water was, moreover, characterized as a basic human right by the United Nations Committee on Economic, Social and Cultural Rights in 2002. ${ }^{48}$ Further, it was acknowledged that rights and obligations between investor and a host state shall be balanced. The amici claimed that the investor in case did not assure the promised number of new connections and the availability of water in many parts of Dar-es-Salaam over the period of the lease declined. ${ }^{49}$ By not fulfilling the promises the investor had created a situation of urgency requiring governmental action. In fact, the Government, carrying the duty to provide access to water to its citizens, had to take action under its obligations under human rights law to ensure access to water for its citizens. ${ }^{50}$

\subsection{Proportionality Test}

Proportionality is at the very centre of legal reasoning. Law incorporates different values (see Part 1 supra) which may conflict with each other. One way of resolving those inconsistencies is to apply the proportionality test. The term "proportion" has its roots in Latin pro poritone - "in respect of (its or a person's) share". ${ }^{51}$ It describes "the relation of one thing to another". ${ }^{52}$ The test of proportionality is of special importance in the fragmented international legal order. Art. 31(3) (c) requires the interpreter of international treaties to apply the rule of systematic integration: "to take into account $[. .$.$] any relevant rules of international law appli-$ cable in the relations between the parties". ${ }^{53}$ In case of investment agreements the arbitrators must not ignore all international legal background relevant in a given

45 The ICSID Convention and the Regulations and Rules adopted pursuant to it are reprinted in ICSID Convention, Regulations and Rules, Doc. ICSID/15, April 2006, at <https:// icsid.worldbank.org/ICSID/StaticFiles/basicdoc/basic-en.htm>, 2 August 2013.

46 Biwater..., para 392.

47 Ibid., paras 379, 380.

4k Ibid., para 380.

49 Ibid., para 383.

si) Ibid., para 387.

51 The New Oxford Dictionary of English, Oxford 1998, p. 1487.

52 Webster's New Dictionary and Thesaurus, New York 1990, p. 435.

53 Art. 31(3)(c) of the Vienna Convention... 
case. Opening the interpretative context to a multitude of potentially applicable agreements provokes a higher potential of normative conflicts with the international normative amalgamate. The test of proportionality is the fundamental tool of balancing legal values, like the one of the access and affordability of water and protection of investment.

In Azurix v. Argentine, ${ }^{54}$ which was an another case related to water services privatization and re-nationalization, the arbitrators referred to Tecmed v. Mexico ${ }^{55}$ report in which the proportionality test of the European Court of Human Rights was quoted: "There must be a reasonable relationship of proportionality between the charge or weight imposed to the foreign investor and the aim sought to be realized by any expropriatory measure [...] a measure must be both appropriate for achieving its aim and not disproportionate thereto". ${ }^{66}$ The Court found relevant that non-nationals "will generally have played no part in the election or designation of its [of the measure] authors nor have been consulted on its adoption", and observed that "there may well be legitimate reason for requiring nationals to bear a greater burden in the public interest than non-nationals." ${ }^{57}$

The proportionality test is of critical importance in evaluation of public policy purposes leading to expropriation. The Amici brief in Suez v. Argentine case provided an interesting analysis of the problem. "It is generally accepted that measures adopted for public health reasons fall within the police powers doctrine. In the instant case, the measures adopted by Argentina sought to, inter alia, ensure access to water and sanitation to the population amidst a severe economic and social crisis. This measure thus averted the public health emergency that would have resulted from the lack of access to clean water and sanitation to millions of people in Buenos Aires. Under the light of human rights law, the police power doctrine operates to distinguish these measures from an otherwise compensable expropriation". ${ }^{58}$

The proportionality test appears to introduce a bridge between investment law and human rights law. Such a juxtaposition was questioned by amici in Suez v. Argentine. In their opinion, the human rights which reflect the recognition of the inalienable, inherent dignity of the human person, where as investor's right are economic policy tools. Such an approach was reinforced by lack of corporations' ius standi before Inter-American Commission on Human Rights and United Nations

${ }^{54}$ Azurix Corp. v. Argentine, Award, 14 July 2006, ICSID Case No. ARB/01/12, para 311.

ss Tecnicas Medioambientales Tecmed S.A. v. The United Mexican States, Award, 29 May 2003, Case No. ARB (AF)/00/2, para 122.

56 Case of James and Others v. The United Kingdom, 21 February 1986.

57 Ibid., para 63, quoted in Azurix v. Argentine..., para 311.

5* Amicus Curiae Submission in ICSID, Case No. ARB/03/19 between Suez, Sociedad General de Aguas de Barcelona, S.A. and Vivendi Universal, S.A. and the Republic of Argentina, at 23, at <http://www.ciel.org/Publications/SUEZ_Amicus_English_4Apr07.pdf>, 15 December 2012. 
Human Rights Committee. ${ }^{59}$ However, this approach is not omnipresent. According to Article 34 of the Convention for the Protection of Human Rights and Fundamental Freedoms, "[t]he Court may receive applications from any person, nongovernmental organization or group of individuals" ${ }^{60}$ This wording did not exclude from claiming corporations like Anheuser-Busch, ${ }^{61}$ an American beer producer. One must not forget that the right of property, also of intangible goods is a human right and therefore juxtaposable with other values protected under the law.

\subsection{Fair and Equitable Treatment}

The Fair and Equitable standard of treatment (hereafter F\&ET standard) is one of the objective standards i.e. non-related to host state's conduct towards other investments. ${ }^{62}$ The goal is to provide the investor a minimum standard of international law. Fairness shall be understood as impartiality in investment treatment. Other components are protection of legitimate expectations, transparency, stability of legal framework, right to due process and protection against denial of justice. $^{63}$

The arbitration decisions related to legitimate expectations component shall be analyzed as a possible tool of justification of states regulatory actions. As Jorge E. Vinuales has correctly put it:

[ $t$ ] he question is whether a foreign investor can reasonably expect, at the time it makes its investment, that if access to water and sanitation by the population becomes threatened, the State would not take measures to ensure access, even if such measures adversely impact the interests of investors. In such a hypothesis, could the investor claim that it has been unfairly and inequitably treated?.64

The mentioned doubt arises when tariff adjustments takes place or not as a result of changing economic and political circumstances. In Azurix v. Argentine the host state's authorities refused to adjust the tariff schedules, when as granted this right once the service was transferred to the new service provider. Politicization of tariff adjustment by the provincial government led with other factors to a cumulative conclusion of the breach of the FE\&T standard. ${ }^{65}$ Similar political circumstances took place in Vivendi II case, when "government, improperly and

sy Ibid., at 25.

(x) Convention for the Protection of Human Rights and Fundamental Freedoms, Art. 34, United Nations Treaty Series, Vol. 213, p. 222.

${ }_{61}$ Anheuser - Busch Inc. v. Portugal, Judgment of Grand Chamber, 11 January 2007.

62 See: M. Jeżewski, Międzynarodowe prawo inwestycyjne, Warszawa 2011, p. 245.

6.3 See: ibid., pp. 221-284.

(4 J.E. Vinuales, 'Access to Water in Foreign Investment Disputes', The Georgetown International Environmental Law Review, Vol. 21 (2009), p. 755.

65 Azurix Corp. v. Argentine..., paras 375-377. 
without justification, mounted an illegitimate "campaign" against the concession, the Concession Agreement, and the "foreign" concessionaire from the moment it took office, aimed either at reversing the privatization or forcing the concessionaire to renegotiate $[\ldots]$ tariffs" 66

The Amici in their submission to the Suez case stipulated that:

the Tribunal should take into account that no government may validly contract away its treaty-based obligations, including its human rights obligations. For example, any commitment that purported to freeze regulation on health, safety, and environmental matters may be incompatible with the government's positive duty to provide protection to the population, including from interference by third-parties. Thus, any BIT interpretation turning Argentina's specific commitments under the concession contract into a commitment to violate its human rights obligations would be contrary to the public order of the State. ${ }^{67}$

Nevertheless, the arbitrators estimated that "Argentina could have attempted to apply more flexible means to assure the continuation of the water and sewage services to the people of Buenos Aires and at the same time respected its obligations of fair and equitable treatment. The two were by no means mutually exclusive". ${ }^{68}$ The tribunal applied an analogical path of reasoning as in the parallel dispute invoking the state of necessity (see Part 5.1 supra) and reached the same conclusion.

\section{Conclusions}

Human rights' dimension in investment disputes brings more attention to pending proceedings. Due to international protests, Bechtel and Abengoa companies which owned Aguas del Tunari decided to abandon their claims. For four years, citizen groups waged a global campaign to pressure Bechtel. They endorsed a legal petition to the World Bank demanding that the case be opened to public participation. Formally, the reason to terminate the concession was the civil unrest. However, its cause was clear: "For indigenous people water is not a commodity, it is a common good. For Bolivia, this retreat by Bechtel means that the rights of the people are undeniable". ${ }^{69}$ This settlement demonstrates the power of public participation. ${ }^{70}$ It also shows the scale of human motivation in case of right to water and the limits of commercialization of traditionally public services.

th Compañia de Aguas del Aconquija S.A. and Vivendi Universal S.A. v. Argentine Republic..., para 7.4.19.

${ }_{67}$ Amicus Curiae Submission, Suez v. Argentina..., para 20.

6* Suez, Sociedad General de Aguas de Barcelona S.A., and Vivendi Universal S.A. v. The Argentine Republic, ICSID Case No. ARB/03/19, 30 July 2010, para 260.

6y Statement by Oscar Olivera, a leader in the Bolivian water revolt, at <http://www.corpwatch.org/article.php?id=13144>, 17 December 2012.

70 Statement by attorney Martin Wagner of Earthjustice, a non-profit, public interest law firm based in Washington, DC, at ibid. 
The decisions related to human right to water and investment protection are of particular importance. They provide guidance in axiology of international law. The arbitrators acting in investment disputes did not close their eyes on human right issues. It proofs that subsystems of international law do not remain in clinical isolation. The method of systematic integration serves as the goal of integrity of international legal order.

The educative function in the area of international law is of particular importance. Judicial decisions, by their very nature "radiate" beyond single domestic legal system. In times of globalization when a growing amount of aspects are regulated by supranational regulations, the educative function of law and judicial decisions spread ideas and values which are encapsulated in them. For that reason, the judicial decisions in cases involving values from different subsystems of international law have a capacity to serve as "litmus paper" for moral and axiological differences within international community.

\section{Abstract}

The world is experiencing a water shortage. This is due not only to the growing population, but first of all to the rising needs of the "blue gold" in the industry and energy production. The liberalization of global and regional trade encourages competitiveness and privatization. As water is becoming a deficit good, the question of the applicability of international economic law shall be raised. Furthermore, the critical analysis is required to assess how the instruments of investment law assure the realization of the human right to water.

Protection of international investors may remain in tension with the fundamental rights of local communities. Foreign investor's right to pursue an economic activity possibly will sometimes hinder or prevent the exercise of the right to water, especially in case of the rise of water services. This, in consequences, raises the question of the legality of expropriation of the foreign investor in order to provide water access. There are already a few cases related to water and water services involving such states as Argentine, Bolivia, Venezuela, Tanzania and Canada. In each of those cases the arbitrators have/had to balance the rights to water and investment protection. This, in consequence, leads into the question on special nature of the human right to water and a need of a more holistic approach in resolving the investment disputes.

The analyzed case of right to water and investment protection is a particular example which presents adequately the problem of fragmentation of international legal order. Lack of uniform legislative centre and of hierarchy of legal sources form its particular nature. Moreover, international law embodied in treaties or custom is often composed of norms having vague and imprecise meaning. This is particularly true in the area of human rights regulations which often encapsulates norms particularly susceptible for a variety of interpretations. The educative function in the area of international law is of particular importance. Judicial decisions, by their very nature "radiate" beyond single domestic legal system. In times of globalization when a growing amount of aspects are regulated by supranational regulations, the educative function of law and judicial decisions spread ideas 
and values which are encapsulated in them. For that reason, the judicial decisions in cases involving values from different subsystems of international law have a capacity to serve as "litmus paper" for moral and axiological differences within international community.

\section{Piotr Szwedo}

Dr. Piotr Szwedo is a lecturer at Faculty of Law at the Jagiellonian University (JU). In 2007 he received his $\mathrm{PhD}$ based on the dissertation entitled 'Retaliations in the Law of the World Trade Organization. He also graduated at the School of French Law (JU/University of Orleans) and the School of American Law (JU/Catholic University of America). He also studied at the University of Bordeaux and was a visiting fellow at the University of Orleans, Columbia Law School, University of Sorbonne, Max Planck Institute for Comparative Public Law and International Law, Heidelberg, University of Kobe and Tsinghua University. In 2010 he received a grant of Canadian government on trade in water. In 2012 he was a visiting lecturer at the universities of Marburg and Nantes as well as a Winiarski Fellow at the Lauterpacht Centre for International Law, University of Cambridge. 